\section{REPS}

3,2

\section{0}

Received 1 July 2018 Accepted 1 July 2018

\title{
East Mediterranean gas: a new arena for international rivalry
}

\author{
Ahmed ElBassoussy \\ Ministry of Trade and Industry, Cairo, Egypt
}

\begin{abstract}
Purpose - This paper aims to explore the international response to the discovery and development of gas fields in the East Mediterranean basin.

Design/methodology/approach - The study applies key concepts into a framework and explores the strategies used by nations for developing their influence in the region.

Findings - The key nation states (the USA and Russia) and the supranational EU are notable in their divergent approaches to obtaining access to and influence regarding the gas fields.

Practical implications - The development of the strategies used by the international rivals for access to the resources available from the offshore oil fields is set to be an area for further study.

Originality/value - This paper offers insight into a developing rivalry over energy security, which will a platform for further investigation throughout the exploitation of the "New Gulf" gas fields.
\end{abstract}

Keywords Pipeline, Energy security, Gas facilities, Concession area, Energy dependency, Offshore field, Liquefied natural gas, Exclusive economic zone, Estimated reserves, Hydrocarbons, East Mediterranean

Paper type Research paper

\section{Introduction}

The repercussions of discovering the massive hydrocarbon wealth in the eastern Mediterranean basin have not been limited to the countries of the region but rather are extended to affect the major global powers of broad international expertise in the field of energy, particularly the EU countries, which suffer from a serious shortage in the energy production equation at the global level. This is also clearly manifested in the competition between Russia and USA to expand their influence over this inflammable region that is rife with disputes and conflicting interests among its parties. Therefore, the discrepancies of major powers interests resulted in other discrepancies in the way each party handles the issue of the eastern Mediterranean gas. However, the common factor among these countries is their efforts to maintain an effective existence in the explored gas fields and the concession areas offered by the countries of the region in international tenders.

\subsection{The theoretical and conceptual premises}

Various theories cared about explaining the nature of the relationship between natural resources (including energy sources) from one part and the break out of conflicts whether on the internal level or in between countries from the other part. However, before interpreting

(C) Ahmed ElBassoussy. Published in Review of Economics and Political Science. Published by Emerald Publishing Limited. This article is published under the Creative Commons Attribution (CC BY 4.0) licence. Anyone may reproduce, distribute, translate and create derivative works of this article (for both commercial and non-commercial purposes), subject to full attribution to the original publication and authors. The full terms of this licence may be seen at http://creativecommons.org/licences/by/4.0/legalcode
Review of Economics and Politica Science

Vol. 3 No. 2, 2018

pp. $70-87$

Emerald Publishing Limited

2631-3561

DOI 10.1108/REPS-07-2018-005 
this relationship, it is worth mentioning the importance of developing a definition for the resources. The World Bank defines "resources" as "naturally originated materials that are essential and useful for mankind." The sources are divided into two groups: renewable resources such as agricultural land, forests and water, and non-renewable resources such as minerals, diamond, gas and petroleum. The ability of a State to access and have control over the resources and wealth is a main determinant in defining the international position of the State in the World Economic System.

The multi classifications of natural resources mainly go back the fact that the "term is wide by its nature," because natural resources could be classified through specialization such as strategic natural resources, energy sources, shared water resources, biological resources, mineral resources and other classifications.

From among natural resources, the research focuses primarily on hydrocarbon resources, in particular, gas and oil sources as being the two main sources of fuel. Oil is a flammable liquid that can be refined and turned into gasoline. Natural gas is used for lighting and producing fuel. The issue of fuel scarcity or difficulty in obtaining it is one of the biggest concerns in both developing and developed countries because they depend primarily on fuel.

Therefore, the increasing demand for obtaining energy sources from developed countries may play an important role in the escalation of conflict and rivalry of major international powers which seek to secure their supplies. Meanwhile, the trans-boundary natural gas transport line and boundary fields also contribute in increasing the tension among various international parties (USA Institute of peace, 2007, p. 4).

1.1.1 Theoretical view about the relation between energy sources and conflict and rivalry. Theoretical literature is divided upon interpreting the relation between conflict and rivalry from one side and the sources of energy from the other side. Theoretical views regarding the causes of the flared competition varied between scarcity and abundance as determinants for the conflict.

1.1.1.1 First: the scarcity of energy sources as a tool for rivalry and conflict. Some call it the "neo-Malthusian view" after the English demographer "Thomas Robert Malthus." This view indicates that the population growth, environmental deterioration, resources depletion and increasing demand for resources lead to the unequal access to those resources. This factor represents a major cause for the escalation of rivalry among the internal elements of the State also increases the risks of the involvement of those States in external conflict with the aim of obtaining energy sources (Colin, 2006, p. 333).

1.1.1.2 Second: abundance of energy sources as a tool for rivalry and conflict. A different view has been introduced that indicates that the abundance of sources resulting due to new discoveries would be a motive for escalating rivalry and conflict within what is called of "resources curse," because the new discoveries and the resulting abundance lead to greed among the parties whether inside the State or among other international parties to obtain a share from this wealth.

Apart from determining the extent to which scarcity or abundance can affect energy sources, each plays a relative role in causing rivalry, which may sometimes turn into conflict (USA Institute of peace, 2007, p. 8).

1.1.2 Conceptual framework. The study raises a number of key concepts that should be identified to determine the phenomena subject of the study and the means of analyzing it accurately. The most prominent of them are as follows.

Energy security: The concept of energy security can be defined through two main inputs; the first is based on energy security through securing supplies and is known as the case when the State or all or most of its citizens and its works shall have access to adequate energy sources at reasonable prices in the foreseeable future without the risks of great 
REPS

3,2

energy downtime. The second input considers energy security through securing the energy supply series at three levels:

(1) upstream level to secure exploration operations and production;

(2) midstream level to secure transportation lines of energy sources whether oil or gas; and

(3) downstream level that includes securing and ensuring the safe transport and distribution of energy sources, as well as investment, maintenance of refineries, transport and distribution networks, storage potential and regulatory and legal frameworks (Arafa, 2014, p. 61).

International conflict: It means a particular competitive position; one party or parties are aware of the incompatibility in the potential future situations in which each of them is compelled to adopt or take an action inconsistent with the potential interests of the other party or parties (Salman, 2007, p. 16).

Geopolitics: According to Douglas Jackson, it is the science that studies the political phenomenon in its dimensions of area. Some American academics also define it as a science that deals with the interaction between geography and political processes. However, the closest definition adopted by the study is the one presented by Roger Casperbsson and Julian, which is the "spatial analysis of the political phenomenon".

Territorial sea: It is a belt of coastal waters extending up to a maximum of 12 nautical miles measured from the baseline of the coastal country. It is considered a full sovereignty area of the State, although foreign vessels, whether military or civilian, are entitled to cross over through so-called innocent passage. The State sovereignty also extends to both the air scope and the seabed under that territory.

Exclusive economic zone: It is defined as the area beyond the territorial sea and adjacent to it and does not extend to more than 200 nautical miles measured from the baselines from which the territorial sea is measured (Seoudi, 1977, p. 3).

\section{Natural gas discoveries in Eastern Mediterranean basin}

The eastern Mediterranean region has been witnessing the discovery of a large number of natural gas fields since 2000. The region is considered highly significant as it possesses enormous strategic reserves that reached potentially 122 trillion cubic feet of gas according to USA Geological survey, 2010. In this context, it is worth mentioning the most prominent discoveries in the eastern Mediterranean basin, taking into consideration the chronology of exploration and development operations (USA Energy Information Administration, 2013). In late 1990s and the beginning of 2000, the American Nobel Energy Company explored the gas field of Mari B, which is $25 \mathrm{~km}$ off the coast of Gaza Strip and at a depth of $243 \mathrm{~m}$ below sea level (Bufman et al., 2014, p. 3). The volume of the reserves has been estimated at 1.1 trillion cubic feet of gas. It has been put into service and production as of 2004 (Wurmser, 2013). The Israeli Delek Group Company owns the right of concession and exploitation of the field by holding (52.9 per cent) of the total share, whereas Nobel Energy Company holds the remaining percentage estimated at (47.1 per cent) (Darbouche et al., 2012, p. 5). In the same year, British Gas Company, an affiliate to British Petroleum Company, announced the discovery of the Gaza Marine Field, which is $36 \mathrm{~km}$ off the coast of the Gaza Strip with a total gas reserve estimated at one trillion cubic feet of gas. The Palestinian authorities signed a four-year agreement for the exploration and development of the field with a number of companies at different rates. On the top of the list of companies comes British Gas (60 per cent), followed by Consolidated Contractors Company (30 per cent) and Palestine 
Investment Fund (10 per cent) (Darbouche et al., 2012, p. 3). However, Israel promptly hampered this agreement due to its determination to control the flow paths of gas from the field to the outer world (Middle East Economic Survey, 2012) by insisting that it is necessary for the field supply to reach Ashkelon first to meet its needs of gas, then afterward to Gaza. Furthermore, Israel set a condition to purchase the gas at prices lower than international rates, a matter that was rejected by the companies (Khadduri, 2011). Consequently, both the Palestinian Authorities and British Gas Company are unable to carry out the exploration operations because of Israel's intransigent stance toward the exploration (Shaffer, 2011, p. 5380). During the same year, another field called Noa, located $36 \mathrm{~km}$ off the coast of Ashdod at a depth of $750 \mathrm{~m}$ below sea level with relatively small reserves that amounted to 0.4 trillion cubic feet of gas, was discovered. Delek Group Company possesses (52 per cent) and Nobel Energy Company (47.1 per cent) of the total concession (Reuters, 2012).

Explorations went on successively throughout a decade until 2009. In 2009, a number of gas fields were discovered, on top of which was Tamar Field, which was discovered in January 2009 and was considered the third largest natural gas field, where its total reserves amounted to around 9.7 trillion cubic feet, according to geological surveys. The Field is located at $90 \mathrm{~km}$ off the coast of northern Israel at 1,650 m below sea level. Four oil companies were licensed to carry out the exploration; these were Nobel Energy, holding 36 per cent of total operations, followed by Delek Group (31.25 per cent), Isramco Company (28.75 per cent) and Dor Gas Company (4 per cent) (Darbouche et al., 2012, p. 4). Moreover, Dalit Field was discovered $60 \mathrm{~km}$ offshore west of Hadera. Its total reserves are relatively low compared to other fields in the basin as it ranges between 0.35 and 0.5 trillion cubic feet of natural gas, which makes it less economically viable and, consequently, more likely to run out of gas supply very shortly (ELNoamaie, 2011, p. 1). Despite its low reserves, four companies participate in its exploitation; these are Nobel Energy (36 per cent), Delek Group (31.25 per cent), Isramco (28.75 per cent) and Dor Gas (4 per cent) (Darbouche et al., 2012, p. 5). By December of the same year, Cyprus authorities announced the discovery of Aphrodite Field, located $180 \mathrm{~km}$ off the southern western coast of Cyprus at a depth of around $1,700 \mathrm{~m}$ below sea level. The total reserve of Aphrodite Field is estimated at nine trillion cubic feet of natural gas. For Cyprus, this field represents a sufficient source to meet all internal gas needs without the need to import gas from other countries. Explorations in Aphrodite Field are carried out only by two companies specialized in this domain: the American Nobel Energy Company, holding 70 per cent of total operations, followed by Delek Group (30 per cent) (Darbouche et al., 2012, p. 5). Furthermore, November 2011 witnessed the discovery of Dolphin Field, located at around $110 \mathrm{~km}$ off Israeli coasts with gas reserves estimated at 0.8 trillion cubic feet of natural gas (Sharof, 2015). Four companies possess the rights of concession, exploration and exploitation of this field; Nobel Energy (39.66 per cent), Avanza Oil (22.67 per cent), Delek Group (22.67 per cent) and Ratio Oil (15 per cent).

Explorations went on at a moderate pace of time until 2012, which marks one of the most significant years in the history of hydrocarbons discoveries in the eastern Mediterranean region. A huge wealth of natural gas was discovered within a series of discoveries, the most prominent of which was Tanin Field, which is called "Temsah" in Hebrew. Tanin, located $120 \mathrm{~km}$ off the coasts of Israel and discovered in February 2001, is the seventh gas field discovered by Israel. The initial estimates showed that the gas reserves amounted to 1.2 trillion cubic feet. Thus, it is considered the third largest field in terms of gas reserves discovered by Israel after the two fields of Leviathan and Tamar. Two companies are executing the exploitation and exploration operations in this field: Nobel Energy (47.06 per cent) and Delek Group (52.49 per cent) (Yeshayahou, 2012). After less than two months, specifically in April, Shimshon Field was discovered $90 \mathrm{~km}$ off western Ashkelon city at 
REPS

3,2

$1,200 \mathrm{~km}$ below sea level with reserves estimated at 0.55 trillion cubic feet. A number of companies carried out the exploration at varying percentages: Isramco Israeli Company (29 per cent), Modiin Energy Company (10 per cent), Naphtha oil (10 per cent), the Israeli INOC Company (11 per cent) and ATP Company (45 per cent) (Modiin Energy, 2012). By June 2012, Israel announced the discovery of Leviathan Field, which is considered the second biggest natural gas field ever discovered in the eastern Mediterranean region. In terms of the potential gas reserves, it amounts to 17 trillion cubic feet. This field is located $135 \mathrm{~km}$ off the northern coast of Israel, near the city of Haifa, at 1,600 m below sea level. The exploration and drilling of the field have been assigned to three major companies at varying percentages, on top of which was Delek Group (45.34 per cent), followed by Nobel Energy Company (39.66 per cent) and Ratio Oil Company (15 per cent) (Darbouche et al., 2012, p. 4).

By 2015, Egypt announced the discovery of the largest gas field of Zohr in eastern Mediterranean by the Italian Company of Eni. Zohr Field is located in the Shorouk concession area, south-eastern of the Mediterranean Sea, in the exclusive economic zone of Egypt. The field is $100 \mathrm{~km}^{2}$ and is 1,450 m deep (The Guardian, 2015), double the Leviathan gas field which was earlier discovered by Israel (The Economist, 2017). The field includes gas reserves estimated at 850 billion cubic meters, which is equal to 30 trillion cubic feet of natural gas. It is expected that the field shall meet the gas needs of Egypt within four years following its discovery (El werdany, 2016). On April 2, 2016, many international news agencies reported that Eni Company has sold 10 per cent of its share in the field to British Petroleum Company (Henderson, 2017, p. 12). Few months later, Russian Company Rosneft announced its acquisition of 30 per cent of shares of the Italian Company of Eni. Thus, the shares of the companies operating the field are as follows: Eni Company (60 per cent), Rosneft Company (30 per cent) and British Petroleum (10 per cent) (Politi and Farchy, 2016).

\section{Patterns of global rivalry over the East Mediterranean basin region gas}

Naturally, the major international powers of broad global expertise in exploring and developing gas and oil fields would have never stayed idle before this massive wealth. In fact, this wealth persuaded some of those powers, in particular, the EU, Russia and USA, to find themselves a foothold in the fields of the region. Each country adopted a different strategy to break through the region, benefiting by the insufficient expertise and potentials of the countries of this region to explore and develop this wealth by themselves and without seeking outside assistance.

\subsection{The European strategy toward the eastern Mediterranean gas}

The energy has become one of the most pivotal issues not only for the Europeans but also for all countries of the world. But the importance for Europe increases with the ongoing fall in the level of the continent's contribution to the world energy equation, which urged the official European institutions to shed more light on energy issues. This also pushed the European Commission President Jean-Claude Juncker, who has been elected since 2014, to form "An Energy Union" called "The Framework Strategy for a Resilient Energy Union with a Forward-Looking Climate Change Policy" (Raines and Tomlinson, 2016, p. 3) that aims at achieving five basic objectives as follows:

(1) Energy security, solidarity and trust: This could simply be achieved by diversifying the offer, and in particular to what is related to natural gas, in addition to enhancing and improving means of cooperation and coordination in encountering crises and enhancing the European role in the international energy market. 
(2) Establishment of an integral European energy market: This can be achieved by focusing on the infrastructure such as pipelines to physically link the markets, in addition to focusing on other matters concerning the activation of the energyrelated legislations and removing organizational and procedural barriers that stand against integration and focusing on poor consumers and customers in the field of energy.

(3) Achieving the efficient use of energy to contribute in balancing the demand: This can be achieved, especially in the fields of construction, building and transportation.

(4) A free-carbon economy: This can be achieved by merging the 2030 climate program with the energy package in the business of EU institutions, continuing the program of reducing and decreasing emissions and maintaining global leadership in the field of renewable energy.

(5) Promoting means of research and innovation: This can be achieved by introducing a new strategy for research and innovation in fields such as renewable energy, smart networks and carbon capture and storage, in addition to nuclear technology (European Commission, 2015).

\subsection{Factors shaping European vision toward East Mediterranean gas}

The EU, as one of the highly influential international powers, has a clear policy toward gas resources recently explored in the eastern Mediterranean region, which emerges from three main factors.

3.2.1 Exploration as an opportunity to diversify energy-attaining sources. The EU considers the massive wealth discovered in eastern Mediterranean as being great opportunities to get rid of Europe's overdependence on the Russian sources of energy as Europe gets more than one-third of its imports from the Russian gas (Moncef et al., 2013, p. 12). EU countries are highly dependent on natural gas imports from abroad. In 2013, their imports amounted to 448.6 billion cubic meters, then slightly fell to 413.7 billion cubic meters in 2014 before witnessing a rise in 2015 to reach 456.4 billion cubic meters. Eventually, during 2016, the EU imports of natural gas remarkably increased to exceed 472.2 billion cubic meters (Figure 1).

The Russian Federation was ranked first among exporters of natural gas to the EU, where their exports amounted to 166.1 billion cubic meters in 2016, representing 35 per cent of total European imports (British Petroleum, 2017a, p. 34) (Figure 2).

3.2.2 Effective participation in the exploration and development of gas fields. European oil and gas companies found themselves in an advanced position in natural gas explorations in eastern Mediterranean countries, particularly Egypt, Cyprus and Palestine. A number of

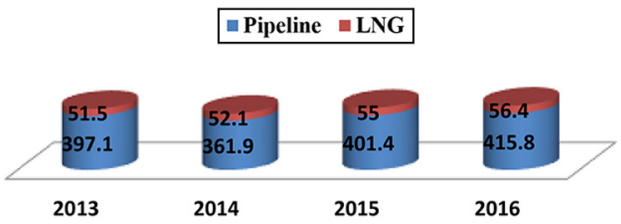

Source: Own elaboration based on data in BP Statistical Review of world Energy June 2017

Figure 1. European imports of natural gas according to their type

(2013-2016)/billion cubic meters 
REPS

3,2

76

companies are participating in these operations, such as British Gas, an affiliate to British Petroleum, the Italian Company of Eni, the French Company of Total and the Dutch Company of Shell.

European companies working in the gas investment sector consider Egypt as the most important country in the eastern Mediterranean region. British Petroleum Company is one of the oldest and biggest companies operating in the field of natural gas exploration, and their investments in Egypt date back to more than five decades. Therefore, the company is now producing 30 per cent of the Egyptian gas and nearly 15 per cent of total oil production in cooperation with a number of other partners. Although its projects are disseminated over almost all parts of the Egyptian country, the most prominent offshore projects are concentrated in two main areas. One is the concession area of West Nile Delta (British Petroleum, 2018), a project that involves the development of northern Alexandria and western Mediterranean Sea gas fields located at a distance of $65-85 \mathrm{~km}$ off the coasts of Alexandria. The project is divided into two stages: the first stage involves the development of the five fields of Taurus, Libra, Fayoum, Giza and Raven, whereas the second stage encompasses the development of another five fields; Maadi, Viper, Ruby, Polaris and Hodoa.

In March 2015, British Petroleum and its German partner RWE DEA signed an agreement with the Minister of Petroleum, the Egyptian General Petroleum Corporation and The Egyptian Natural Gas Holding Company to develop the first stage of the project against investments that amounted to $\$ 12 \mathrm{bn}$. First-stage fields are expected to have gas reserves estimated at five trillion cubic feet, in addition to 55 million barrels of condensed oil. Technically, according to the project, both Taurus and Libra Fields will be linked to Gas Burullus Facilities in Al-Burullus area, while both Giza and Fayoum Fields will be linked to the already existing onshore Rosetta Gas Treatment Plant in Rasheed. Raven Field will be linked to another factory that will be established in Rasheed as well (Offshore Technology, 2017a, 2017b).

First stage of production began on March 24, 2017, when the British Company announced the commencement of the actual production of Taurus and Libra Fields that contain nine wells; six in Taurus Field and three in Libra Field. As for the other three fields, in which work has not started yet, they will contain 12 natural gas wells according to the company. It is worth mentioning that British Petroleum Company owns 82.75 per cent of the project, whereas its German partners hold 17.75 per cent (British Petroleum, 2017a, 2017b, 2017c).

On the other hand, the projects of British Petroleum Company are also concentrated on the North Damietta concession area, where the company discovered three gas fields. The first field was Salamat Field. On September 9, 2013, British Petroleum Company announced

Figure 2.

European imports of natural gas from Russia/2016

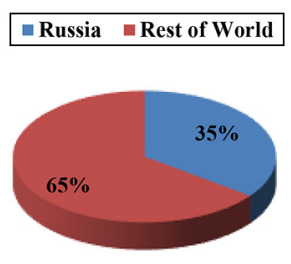

Source: Own elaboration based on data in BP Statistical Review of world Energy June 2017 
the discovery of the natural gas field of Salamat in North Damietta concession area within the framework of North Damietta agreement that was signed in 2010. The field is $649 \mathrm{~m}$ deep, and the total depth of the well reaches almost 7,000 m, which makes it the deepest well ever drilled in the Nile Delta area (EGAS Report, 2015). Bob Dudley, British Petroleum Head of Explorations Sector, said: "the success of the Salamat discovery confirms the existence of hydrocarbon resources within a geological formation of $50 \mathrm{~km}$ long with a hydrocarbon column of 180 meters high, which enhances the company's trust in the economic feasibility of deep layers in East Delta and North Damietta." It is worth mentioning that British Petroleum Company's share in the field is 100 per cent (Ahram Online, 2017a, 2017b). By March 2015, the company announced the discovery of the second gas field of Atoll, at $923 \mathrm{~m}$ deep; the depth of the well reaches $6,400 \mathrm{~m}$, which was measured using the sixth-generation semi-submersible rig Maersk Discoverer. The field is located $80 \mathrm{~km}$ from North Damietta and $45 \mathrm{~km}$ off the Temsah offshore facilities. The potential reserve of the field is 1.5 trillion cubic feet of gas and 31 million of oil barrels. This field is expected to feed the Egyptian market with 300 million cubic feet of gas on a daily basis once its production operations start in 2018 as scheduled; it is also worth saying that the share of British Petroleum Company is estimated at 100 per cent (Offshore Technology, 2017a, 2017b). On March 26, 2017, a statement by British Petroleum Company announced the discovery of the third field of Qattameya Shallow-1 in the concession area of North Damietta, to a total depth of 1,961 m in water depth of approximately $108 \mathrm{~m}$ using El Qaher II jack-up rig. The company asserted, through the wire line logs pressure data and fluid samples, the existence of a gas layer of 37 $\mathrm{m}$ of thickness in high-quality rocks of Pliocene sandstones formation. The well is located $60 \mathrm{~km}$ off North Damietta, $30 \mathrm{~km}$ off south western Salamat Field and $35 \mathrm{~km}$ off western Ha'py Offshore Facilities. British Petroleum Company's share in this discovery is 100 per cent (British Petroleum, 2017a, 2017b, 2017c).

Eni, the Italian Company, is considered one of the oldest companies operating in Egypt. It started explorations and drilling in the Egyptian fields since 1954 by IEOC Company's branch in Egypt (Eni, 2018). The company's total number of licenses amounted to 53 exploration licenses covering an area of $11,691 \mathrm{~km}^{2}$ through which it discovered 59 gas and oil fields (Nour, 2015). However, the period from 2015 to 2017 witnessed a significant leap in the activities of Eni Company in Egypt. On January 14, 2015, the company announced that it obtained the approval of the Egyptian Government for natural gas exploration in the two new sectors of North Leil, a fully acquired field by the Italian Company, which covers an area $5,105 \mathrm{~km}^{2}$, and Karawan concession of which both Eni and British Petroleum are equal partners (Eni, 2015). In line with Eni's approach to pump more investments in natural gas Egyptian fields, the company signed an agreement to amend the work program to implement exploratory and developmental activities in the concession areas of Balaeim in Sinai, Abu Madi in the Nile Delta, Ashrafi in the Gulf of Suez, North Port Said in the Mediterranean Sea and Baltim in the Nile Delta. The Italian company and its partners, according to the agreement, have initiated a number of investments estimated at $\$ 5 \mathrm{bn}$ in Sinai and Abu Madi to execute a work program that involved explorations, development and operation for four years (Eni, 2016). On August 30, 2015, the company announced the discovery of Zohr Field in Shorouk concession area that contains, as per estimations, 850 billion cubic meters of gas reserves, which is equivalent to 5.5 billion equivalent oil barrels. Thus, this field became the greatest exploration realized in Egypt and the Mediterranean Sea. Production was expected to start in December 2017 (Ahram Online, 2017a, 2017b). By December 2016, the two companies signed two new agreements with the Egyptian Government for gas exploration in the two regions of North El Hammad and North Ras El Esh in the Mediterranean Sea. Eni Company acquired 37.5 per cent of North El 
REPS

3,2

Hammad concession, which covers an area of $1,927 \mathrm{~km}^{2}$, while British Petroleum Company acquired 37.5 per cent and Total Company acquired 25 per cent. Furthermore, Total acquired 50 per cent of Ras El Esh concession, which covers $1,389 \mathrm{~km}^{2}$, whereas British Petroleum Company acquired the remaining percentage (Eni, 2016).

In Cyprus, European countries had a powerful presence on the map of gas fields explorations, especially British Gas Company, which announced in November 2015 its acquisition of 35 per cent of Aphrodite Field gas reserves from the American Nobel Energy Company in a deal worth of $\$ 165 \mathrm{~m}$ (Reuters, 2015). In 2016, both Eni and Total companies managed to get the individual exploration rights in Block 8, while a consortium formed of Eni, Total and the Cyprus B companies obtained the exploration concession in Block 6 according to the Cyprus' third license for hydrocarbon materials exploration in the Exclusive Economic Zone of Cyprus (Republic of Cyprus, Ministry of Energy, commerce, Industry, and Tourism, 2016).

On the Palestinian level, British Gas Company was the first company to conclude agreements with the Palestinian authorities aiming at exploration and investment in offshore gas fields. In November 1999, the Palestinian authorities concluded a 25-year agreement with the British Company, which allowed the company and its partners, in particular Consolidated Contractors Company and the Palestinian Investment Fund, to carry out gas exploration off the Palestinian coasts. Consequently, in 2000, the company discovered two gas fields, Gaza Marine 1 and Gaza Marine 2, to have potential gas reserves of 1.4 trillion cubic meters worth of $\$ 4 \mathrm{bn}$. However, the project was suspended because of the opposition of the Israel authorities (Alquds Alarabi, 2015).

3.2.3 Supporting common natural gas exportation projects. The Europeans realized from the very beginning that the optimal benefit from the massive gas wealth in eastern Mediterranean mainly depends on creating a strong cooperation among the countries of region, especially in gas export. This pushed the EU to support all projects and movements of cooperative nature, which is likely to pave the way for the Mediterranean gas exportation (Charles et al., 2016, p. 17). The most prominent features of the European support for cooperation projects in the field of eastern Mediterranean gas are represented as follows:

- In 2015, the EU approved the gas transport Pipeline project of EastMed as being a project of common interest, including it in the second list of projects of this type and considering it as a part of Southern Gas Corridor Projects.

- The project should be listed in the last Ten Years Development Plan in coordination with European Network Transportation System Operators of Gas to create a consolidated gas market and a transportation network capable of fulfilling Europe's current and future needs (IGI Poseidon, 2018).

- Participation should be done to finance the initial feasibility studies of the project. During the period from 2015 to 2016, IGI Poseidon Company conducted Pree-FEED studies at $\$ 4 \mathrm{~m}$, in which the EU contributed $\$ 2 \mathrm{~m}$, which equals 50 per cent of the total cost of the study, which, accordingly, confirms the importance of this project for the Europeans. The initial outcomes of the feasibility study resulted in three main things: the project is technically applicable, economically fruitful and commercially competitive (Margheri, 2017, p. 3). In the meantime, these common cooperative projects, including the establishment of an integral energy market, are still facing some challenges, on top of which is the market risks relating to projects financing and including matters related to definition and supplies, in addition to technical and engineering issues and environmental and legal risks, in particular those relating to the organizational uncertainty in the Middle East in the absence of 
an international binding legal framework for all parties. This is in addition to political risks, particularly and to a great extent, with the prevailing unstable geopolitical climate (Zemach, 2016, p. 11).

Within the framework of analyzing the European approach in dealing with the eastern Mediterranean gas discoveries, the followings results are observed:

- The eastern Mediterranean gas represented a potential opportunity for the Europeans to liberate themselves from Russian dependency in the field of natural gas.

- There is dependency of the European side to create an area of common interest with the parties of the region, which was not only manifested in the practical steps but also in the continuous confirmation at the level of statements, which is considered an extremely pivotal psychological element to the eastern Mediterranean countries.

- There is lack of interest in Israel's gas on the part of the European companies and concentration on Egyptian and Cyprus gas only, leaving the Israeli arena for the American and Israeli companies within the framework of direct or implied agreement among global powers to divide the economic gains of the region.

\subsection{Russia's strategy toward the eastern Mediterranean gas}

Despite the prevailing concept that Russia has no interest in gas discoveries of the eastern Mediterranean region, it seems that the Russian officials have finally realized the significance of this region, not only for the sake of gas but also for being of a special strategic nature, which pushed them, during recent years, to get involved in gas projects at all levels. Since 2013, Russia has been accessing the Lebanese gas market where four major Russian oil and gas companies, Rosneft and Gazprom State-owned companies and Novatek and Lukoil private sector companies, announced their interest in investing in ten blocks in the Lebanese Exclusive Zone (Sputnik News, 2013). In the same month, Gobran Basil, Lebanon's Minister of Energy, asserted during his visit to Moscow that his country has signed a memorandum of cooperation in the field of energy with the Russian side by which Russia is allowed to conduct natural gas exploration and development off the Lebanese coasts (Stergiou, 2017, p. 107).

At the Syrian level, in spite of the ongoing state of war for more than five years that resulted in a fierce struggle for power, on December 25, 2013, Russia could manage signing an agreement with the Syrian authorities through the government-controlled Soyuzneftegas Group. By this agreement, the company shall carry out survey and exploration off the Syrian coasts in what is called Block 2 for 25 years with investments estimated at $\$ 90 \mathrm{~m}$ (Coats, 2014), of which $\$ 15 \mathrm{~m}$ is dedicated to cover the costs of the survey study costs and another $\$ 75$ for the initial drilling works. This concession is considered the first to be signed in relation to marine areas off the coasts of Syria in the Mediterranean Sea. It is worth mentioning that the current onshore gas and oil fields are located in Euphrates River basin and are considered quite small as per other discoveries standards in the Middle East. These fields are currently under the control of the Assad's opposition groups, in addition to the embargo imposed on their exports by the International Security Council (Henderson, 2013).

Despite the tense situation in the Palestinian arena, Russia continued its efforts to place a foothold in the Palestinian gas, which could potentially be benefitted by in case of reaching an agreement with the Israeli side in the future. On January 23, 2014, the Palestinian President, Mahmoud Abbas Abu Mazen, signed, during his visit to the capital city of Moscow and meeting the Russian President, Vladimir Putin, and his Prime Minister, Dmitry 
REPS

3,2

Medvedev, an agreement that entitles the Russian party to invest in the development of Gaza Marine fields off Gaza Strip coasts (Yorgancioglu, 2015, p. 1). On June 21, 2014, the Undersecretary of Ministry of National Economy, Taiseer Amr, and the Deputy Minister of Economic Development in Russia, Lechachov, signed the first round protocol for the meetings of the high-level Palestinian-Russian action group to hold consultations in the economic and investment issues with the participation of the Palestinian Ambassador to Russia, Fa'ed Mostafa. According to the protocol, the two sides agree to study the possible options for cooperation in the field of gas, oil, electric energy, industry and transportation, as well as activating cooperation projects of priority between Russia and Palestine including processing the financing issues. In the same context, the two sides confirmed the role of Gazprom in studying the cooperation possibility with the Palestinian Investment Fund in the field of gas and oil exploration and extraction. The two parties also pointed out that Technopromexport is ready to take part in building the power plants in Palestine after determining the sources of financing the construction (Palestine Today, 2014). By September 2015, Abu Mazen visited Moscow once more, where he further discussed with the Russian President, Vladimir Putin, the means of cooperation in the energy projects in Palestine, and in particular the possibility that Gazprom Company develops Gaza Marine Field, but no specific clear formula was reached in light of the continuous opposition of Israel (Sputnik Arabic, 2015).

Egypt has also been an area of the Russian interest in gas, especially after the discovery of "Zohr" Field with its huge reserves. This was revealed after the announcement of Igor Sechin, CEO of Rosneft, on December 12, 2016, that his company would enter into the agreement of "Shorouk" concession, following an agreement signed between the Italian company "Eni" and his company. In accordance with that agreement, Rosneft owns 30 per cent of Shorouk concession worth $\$ 1.1 \mathrm{bn}$. Furthermore, the Russian company owns 15 per cent of the shares of the concession operating company. This was a coalition between IOK, a branch of "Eni" in Egypt, and Egyptian Natural Gas Holding Company. Moreover, there is an option for Rosneft to buy an additional 5 per cent share under the same conditions. Thus, Rosneft owns a share in the largest gas field ever discovered in the Mediterranean, Zohr Field, whose reserves are estimated at 850 billion cubic meters of gas (Deloitte, 2017).

On the Israeli level, Russian attempts to take part and benefit by the huge amounts of gas discovered have not stopped since 2012. Gazprom Company bid for a share of 30 per cent of the concession of Leviathan Field. The Russian company news agency reported that it had submitted the highest bid, yet eventually lost the bid for the Australian Woodside Energy, a company that was shut down shortly afterward. It is reported that the Russian President, Vladimir Putin, had visited Israel in July 2012 to support the Russian state-owned Company (Stergiou, 2017, p. 106).

The Russian pursuit continued to infiltrate into the Israeli gas market, until Gazprom was able, in February 2013, to persuade the Israeli side to cooperate, a matter that resulted in signing an agreement between the company and the Israeli side to exclusively obtain liquefied natural gas from Tamara and Dalit Fields for 20 years (Thompson and Sarah, 2015, p. 6).

Although the agreement has not been translated into reality and has not been applied, it could be considered a serious attempt by Russia to hold a significant position on the Israeli gas map (Thompson and Sarah, 2015, p. 7). The Russian efforts have not stopped at this point; several months after signing the agreement, Gazprom entered into a new round of negotiations with the aim of buying 30 per cent share of Leviathan gas field. The offer included introducing a new strategic partner in the field that would offer what the current 
partners could not, especially the financial capacity and the technical and managerial expertise that could exploit the huge reserves of the field as soon as possible. In spite of the extreme enthusiasm of Dalik Group officials to introduce the Russian company, the American partner in the field, Nobel Energy Company, objected. The company preferred to introduce a Western and not a Russian party, in particular the Australian Woodside Company, which had to drop out at the last minute before the signing of contracts with the justification of the instability of the Israeli gas sector investments. It is worth mentioning that a number of major companies operating in the oil and gas sector, such as the South Korean Kogas, the Chinese CNOOC and the Australian Woodside, have showed interest in entering into a partnership of the field of Leviathan due to its strategic importance as it contains large quantities of gas (Cohen, 2016a).

Despite the obstacles that the partners placed in front of the Russian state-owned company, Russian officials did not despair and continued their attempts. In the same context, a Russian delegation, including a number of representatives of companies operating in the gas sector, headed by Deputy Minister of Energy Anton Inyutsyn went to Israel on a two-day visit on July 14, 2015, to discuss possible cooperation in the field of natural gas. On the sidelines of the visit, Inyutsyn met the head of Manufactures Association, "Shraga Brosh," and the representatives of the companies to discuss ways of strengthening Israeli-Russian cooperation, especially in the field of energy transfer and gas export, as well as strengthening cooperation and exchange of information in the same field (Cohen, 2016b). However, the Russian attempts relatively paid off on June 13, 2016, after Israeli Prime Minister Benjamin Netanyahu called on Russian companies to invest in the Israeli gas sector in the Mediterranean during a joint press conference with President Vladimir Putin in Moscow. Netanyahu stated "Our doors are open to all companies with extensive experience in the development of the gas field, including Russian companies for sure" (Globes, 2016).

3.3.1 Reasons behind Israeli acceptance of Russian gas partnership. The abovementioned discussion shows that Israel has opened the door to Russian investments in the field of gas, due to several reasons that are not only related to the special aspects of energy but also to political and geo-strategic ends, at the forefront of which are the following:

- Protecting Israeli gas facilities in the East Mediterranean: It is known that Hezbollah is the main, if not the only, threat to the gas infrastructure in Israeli fields. Therefore, it was natural to turn Russia into a balanced element in the Israeli energy equation that would represent a self-securing factor. As Hezbollah is one of the main pillars of the Russian-Shiite alliance in the region, Hezbollah would not harm the interest of one of its most important allies in the international arena represented by the Russian side. This is what was explicitly expressed by the Russian President during his attempts to convince the Israeli prime minister to develop a partnership with Gazprom in the Leviathan Field when the Russians promised to prevent extremist groups from attacking the Israeli gas infrastructure.

- Ensuring the provision of a channel for the export of Israeli gas: As the Russian involvement represents an optimal solution in the process of exporting gas to other countries, especially after Moscow announced its commitment to invest tens of billions of dollars not only in development processes but also in transferring and exporting of leviathan gas field, particularly at the time when Tel Aviv suffered from the failure of reaching an agreement with other countries in the region, especially Turkey and Cyprus, on exporting its gas to Europe (Josh, 2016). 
REPS

3,2

\subsection{US strategy toward the eastern Mediterranean gas}

A major breakthrough in gas discoveries in the eastern Mediterranean region has raised tension among countries in the region. Hydrocarbon resources have become a new source of regional conflict, which has been reflected in US attitudes toward the eastern Mediterranean gas discoveries. Therefore, the US vision for Mediterranean gas is governed by three main determinants:

(1) Gas as an access for peace in the region and the preservation of Israel's security: The USA attempted to use and adapt natural gas in the framework of the IsraeliPalestinian peace process. This was reflected in the proposal made by John Kerry, US Secretary of State, in May 2013 in what is named as "The Economic Plan for the Palestinian Territories" or "Palestine Economy Initiative," which aims at developing the economy in the West Bank and Gaza Strip for three years as a foundation for a comprehensive political settlement to end the Israeli-Palestinian conflict (DE Micco, 2014: 20). The initiative also focused on the gas issue and suggested the necessity to start negotiations between both parties to develop "Gaza Marine" field to make it easy to construct four power stations in Gaza Strip (Office of The Quartet Representative Tony Blair, 2013).

(2) Israeli security: On the level of the direct Israeli security, the USA conducted some naval military maneuvers alongside Israel and Greece from March 26 to April 5 with the purpose of defending natural gas drilling facilities in the Mediterranean (Gabe, 2012).

(3) Gas as a tool to bring its allies closer: It is known that the eastern Mediterranean region includes a number of USA's allies whose interrelations are a relative deteriorating as per each case independently. At the Israeli-Turkish level, many US officials, in the forefront comes the American diplomat Amos Hochstein, the special envoy of the US Secretary of State for Energy, have emphasized on August 21, 2016, that the large quantities of gas in the eastern Mediterranean region represent a real opportunity for the countries of the region, especially Israel and Turkey, to strengthen their relationship, particularly as Israel continues to develop Leviathan Field and the possibility to construct a pipeline to export the Israeli gas via Turkey to Europe. Thus, the USA supported Israeli-Turkish reconciliation agreement as it paves the way for this process (Wainer, 2016).

(4) Achieving economic gains and interests: This could be done through the control of US companies, in particular, "Nobel Energy," on gas investments in the Levant Basin, especially off the Israeli and Cypriot coasts and, in particular, "Aphrodite" Field located in Block 12. However, it seems that the American companies have not been satisfied with those investments, as they are seeking to expand them, especially in the Lebanese maritime areas, which can only be achieved if the American mediation efforts succeed to end the Israeli-Lebanese conflict on the maritime triangle, especially since the Lebanese authorities have warned the American company "Nobel Energy" to carry out any exploration activities in the disputed area with Israel (DE Micco, 2014, p. 20).

\section{Conclusion}

The huge gas discoveries in the eastern Mediterranean region have become the focus of all major international powers, especially the USA, Russia and the EU. The region is seen as the future of the world's gas production. The motives of international powers to take care of the 
region's gas vary to great extent. However, the EU sees otherwise as it represents a real opportunity to ensure energy security through reducing the dependence on Russian gas, while Russia and USA focus mainly on the political aspect more than the economic one. Moreover, the equation of exploration and discovery of gas has been different recently. The American and European companies are no longer the only dominants parties over the gas market as Russia has begun to gradually penetrate the region.

On the other hand, it is quite clear that the Russian penetration method of the gas market is different from the European and American ones. While European and American companies are focusing on vigorously accessing and bidding to obtain exploration rights in offshore concession areas offered by the coastal state, Russia is adopting a different pattern that mainly depends on buying shares of already discovered fields via American and European companies. The exception shall be in the case when Russia obtains the concession right for exploration in Block 2 off the Syrian coast, which could be read in a purely political framework regarding the Russian presence in the region to support the regime of Bashar AlAssad, not economically.

\section{References}

Ahram Online (2017a), "BP makes third gas discovery in Egypt's North Damietta concession", available at: http://english.ahram.org.eg/NewsContent/3/12/261668/Business/Economy/BP-makes-thirdgas-discovery-in-Egypts-North-Damie.aspx (accessed 20 September 2017).

Ahram Online (2017b), "Egypt's Zohr gas field production is expected before end of 2017, ENI boss tells SISI", available at: http://english.ahram.org.eg/NewsContent/3/12/254507/Business/Economy/ Egypts-Zohr-gas-field-production-is-expected-befor.aspx (accessed 31 June 2017).

Alquds Alarabi (2015), "Gaza's marin gas field is an unexploited treasure off the coast of Gaza, which suffers from the specter of fuel shortages", Naif Arab University for Security Sciences, Center for Studies and Research, 2014, available at: www.alquds.co.uk/?p=457867 (accessed 22 August 2017).

Arafa, K. (2014), Energy Security and Its Strategic Implications, 1st ed., Naif Arab University for Security Sciences, Center for Studies and Research, Riyadh.

British Petroleum (2017a), "BP statistical review of world energy June 2017”, Energy Outlook, London, available at: www.bp.com/content/dam/bp/en/corporate/pdf/energy-economics/statistical-review2017/bp-statistical-review-of-world-energy-2017-full-report.pdf (accessed 1 July 2017).

British Petroleum (2017b), "BP announces start of production from West Nile Delta development achieving first gas eight months ahead of schedule and production 20 per cent above plan", available at: www.bp.com/en/global/corporate/media/press-releases/bp-announces-start-of-productionfrom-west-nile-delta-development.html (accessed 3 May 2017).

British Petroleum (2017c), "BP makes third gas discovery in North Damietta concession, East Nile Delta, Egypt", available at: www.bp.com/en/global/corporate/media/press-releases/bp-makesthird-gas-discovery-in-east-nile-delta.html (accessed 15 May 2017).

British Petroleum (2018), "BP in Egypt", available at: www.bp.com/en/global/corporate/what-we-do/bpworldwide/bp-in-egypt.html (accessed 20 January 2018).

Bufman, M., Raz, E. and Hager, N. (2014), "The potential of the natural gas in the Israel economy", BANK LEUMI LE-ISRAEL, Tel Aviv, available at: www.chamber.org.il/media/150344/thepotential-of-natural-gas-in-the-israeli-economy-april-2014.pdf (accessed 12 November 2017).

Charles, E., John R., Harry T. and David K. (2016), "Hydrocarbon developments in the Eastern Mediterranean: the case for pragmatism”, Eurasian Energy Futures Initiative, Atlantic Council, p. 17, available at: www.atlanticcouncil.org/images/publications/Hydrocarbon_ Developments_in_the_Eastern_Mediterranean_web_0801.pdf 
REPS

3,2

Coats, C. (2014), "Russia finds path into Mediterranean gas through Syria", Forbes, available at: www. forbes.com/sites/christophercoats/2014/01/16/russia-finds-path-into-mediterranean-gas-throughsyria/\#2beeff1b2a62 (accessed 16 November 2017).

Cohen, H. (2016a), "Gazprom's interest in Israeli gas reservoir Leviathan is a strategic issue for Russian president Vladimir Putin”, available at: www.globes.co.il/en/article-russia-wants-share-in-israeligas-1001119921 (accessed 18 October 2017).

Cohen, H. (2016b), "Russia wants share in Israeli gas", Globes, available at: www.globes.co.il/en/articlerussia-wants-share-in-israeli-gas-1001119921 (accessed 10 August 2017).

Colin, H. (2006), States, Scarcity, and Civil Strife in the Developing World, Princeton University Press, Princeton, NJ, p. 333.

Darbouche, H., El-katiri, L. and Fattouh, B. (2012), "East Mediterranean gas: what kind of a gamechanger?", Oxford Institute for Energy Studies (OIES), p. 4, available at: www.oxfordenergy.org/ wpcms/wp-content/uploads/2012/12/NG-71.pdf (accessed 15 August 2017).

Deloitte (2017), "Russia and Italy doing business together", Deliotte CIS Research Center, p. 11, available at: www2.deloitte.com/ru/en/pages/research-center/articles/russia-and-italy-doing-business-together. html (accessed 10 February 2018).

De Micco, P. (2014), "The prospect of Eastern Mediterranean gas production: an alternative energy supply for the EU: in-depth analysis", Policy Department, Directorate-General for External Policies, European Parliament, Brussels, p. 20, available at: www.europarl.europa.eu/RegData/ etudes/briefing_note/join/2014/522339/EXPO-AFET_SP\%282014\%29522339_EN.pdf (accessed 25 July 2017).

EGAS Report (2015), “Annual report 2014-2015”, Cairo, available at: www.egas.com.eg/docs/pdf/ Egas_EN_2015_Final\%20@3-9-2015.pdf (accessed 21 August 2017).

ELNoamaie, S. (2011), "Israeli gas discoveries: strategic value and regional implications", Doha institute, available at: www.dohainstitute.org/ar/lists/ACRPS-PDFDocumentLibrary/document_4FB28AF3. pdf (accessed 15 February 2017).

Eni (2015), "Eni awarded two new exploration license in the Egyptian offshore Mediterranean sea", available at: www.eni.com/en_IT/media/2015/10/eni-awarded-two-new-exploration-licenses-inthe-egyptian-offshore-of-the-mediterranean-sea (accessed 27 September 2017).

Eni (2016), "Eni in Egypt", available at: www.eni.com/docs/it_IT/eni-com/documentazione-archivio/ documentazione/brochure/eni_egitto_2016.pdf (accessed 10 September 2017).

Eni (2017), "Eni's activities in Egypt", available at: www.eni.com/enipedia/en_IT/internationalpresence/africa/enis-activities-in-egypt.page (accessed 29 August 2017).

Eni (2018), "Eni signs concession agreements for two exploration blocks in the Egyptian mediterranean", available at: www.eni.com/docs/en_IT/enicom/media/press-release/2016/12/PR_EGASBR_2016.pdf (accessed 19 October 2017).

European Commission (2015), "A framework strategy for a resilient energy union with a forwardlooking climate change policy, COM/2015/080 final”, available at: http://eur-lex.europa.eu/legalcontent/EN/TXT/?uri=COM\%3A2015\%3A80\%3AFIN (accessed 10 July 2017).

Gabe, F. (2012), "Joint Israeli-Greek military drill seen by some as rebuff to Turkey”, [Online] The Times of Israel, available at: www.timesofisrael.com/israel-greek-us-military-run-joint-exercises-ineastern-med/ (accessed 17 April 2017).

Globes (2016), "Netanyahu invites Russia to develop Israel's gas fields", available at: www.globes.co.il/ en/article-netanyahu-invites-russia-to-develop-israels-gas-fields-1001130872 (accessed 20 May 2017).

Henderson, S. (2013), "Russia-Syria offshore gas deal injects new factor into peace talks", Washington institute, available at: www.washingtoninstitute.org/policy-analysis/view/russia-syria-offshoregas-deal-injects-new-factor-into-peace-talks (accessed 7 September 2017). 
Henderson, J. (2017), "Russian LNG: progress and delay in 2017”, Energy Insight, The Oxford Institute for Energy studies, Oxford, p. 12, available at: www.oxfordenergy.org/wpcms/wp-content/ uploads/2017/03/Russian-LNG-\%E2\%80\%93-Progress-and-delay-in-2017-OIES-Energy-Insight. pdf (accessed 20 September 2017).

IGI Poseidon (2018), "Eastmed: a direct link to new sources for Europe", available at: www.igi-poseidon. com/en/eastmed (accessed 20 August 2017).

Josh, C. (2016), "Why Russia may be a smart business partner for Israel?", Reuters News Agency, available at: http://blogs.reuters.com/great-debate/2016/02/23/why-russia-may-be-a-smartbusiness-partner-for-israel/ (accessed 23 February 2018).

Khadduri, W. (2011), "East mediterranean gas: reality and expectations", The Journal of Palestine Studies, Spring, Vol. 22 No. 86, p. 76.

Margheri, M. (2017), "The East med pipeline project: a project of common interest for the diversification of gas supplies to Europe".

Moncef, B., Allal, S., Kappauf, J. and Preure, M. (2013), “Towards a Euro-Mediterranean energy community: moving from Import-Export model to a new regional energy model”, Institut De Prospective Economique Du Monde Mediterraneen, No advance toward development for offshore Gaza Marine, Middle East Economic Survey (MEES), 55(40), 28 September, 2012, p. 12.

Nour, S. (2015), "Discovery of the decade: Eni's new deepwater find biggest ever in Egypt”, Egypt Oil and Gas Newspaper, available at: http://egyptoil-gas.com/features/discovery-of-the-decadeenisnew-deepwater-find-biggest-ever-in-egypt/ (accessed 13 August 2017).

Office of The Quartet Representative Tony Blair (2013), "Summary of the Palestinian economic initiative", Ad-Hoc Liaison Committee Meeting, New York, NY, p. 3, available at: www.quartetrep.org/files/ image/quartet/documents/ahlc-sept-2013.pdf (accessed 16 August 2017).

Offshore Technology (2017a), "Atoll gas field, North Damietta offshore concession, East Nile delta, Egypt”, available at: www.offshore-technology.com/projects/atoll-gas-field-north-damiettaoffshore-concession-east-nile-delta/ (accessed 4 August 2017).

Offshore Technology (2017b), "West Nile delta project”, available at: www.offshore-technology.com/ projects/west-nile-delta-project/ (accessed 17 March 2017).

Palestine Today (2014), "Palestinian-Russian agreement for cooperation in the fields of oil, gas and energy", available at: https://goo.gl/7gfXmb (accessed 20 July 2017).

Politi, J. and Farchy, J. (2016), "Eni sells 30\% stake in Egyptian gas field to Rosneft", The Financial Times, available at: www.ft.com/content/257abfdc-c070-11e6-9bca-2b93a6856354 (accessed 8 July 2017).

Raines, T. and Tomlinson, S. (2016), "Europe's energy union: foreign policy implications for energy security, climate and competitiveness", Europe Programme Energy, Environment and Resources, Chatham House, The Royal Institute of international Affairs, available at: www.chathamhouse. org/sites/files/chathamhouse/publications/research/2016-03-31-europe-energy-union-rainestomlinson.pdf (accessed 18 November 2017).

Republic of Cyprus, Ministry of Energy, Commerce, Industry, and Tourism (2016), “3rd licensing round: council of ministers decision on selected applicants for negotiations", Cyprus, available at: www. mcit.gov.cy/mcit/mcit.nsf/All/81B8A71BF27CA06AC2258090003D4D45?OpenDocument (accessed 30 December 2016).

Reuters (2011), "Indicators for presence of natural gas in new Israeli exploration site", available at: https://ara.reuters.com/article/arabicBusinessNews/idARAGAW64100120111106 (accessed 23 April 2017).

Reuters (2012), "Noa well starts supplying Israel with natural gas", available at: www.reuters.com/ article/2012/06/24/us-noa-israel-idUSBRE85NOGR20120624 (accessed 23 July 2017).

Reuters (2015), "BG group pays $\$ 165$ million for stake in Cyprus gas field", available at: http://uk. reuters.com/article/uk-cyprus-energy-noble-energy-idUKKBN0TC1BQ20151123 (accessed 30 June 2017). 
REPS

3,2

Salman, M. (2007), International Conflict over Nile Basin Water, Center for Research and Political Studies, Cairo.

Seoudi, A. (1977), Geography and International Problems, Model Library, Cairo.

Shaffer, B. (2011), "Israel-New natural gas producer in the mediterranean", Energy Policy, Vol. 39 No. 9, p. 5380 .

Sharof, H. (2015), "Israel and offshore gas", National Council for Researches and Opinion Polls, available at: $\mathrm{http} / / \mathrm{ncro} . \mathrm{sy} / \mathrm{p} \mathrm{p}=1952$ (accessed 30 June 2016).

Sputnik Arabic (2015), "Vladimir Putin discusses with Mahmoud Abbas the issue of participation of Russian companies in energy projects in Palestine", available at: https://arabic.sputniknews. com/world/201509221015702382/ (accessed 21 March 2018).

Sputnik News (2013), "Russia-Lebanese ties strengthen ahead of disputed gas fields tender", available at: https://sputniknews.com/russia/20131011184062056-Russia-Lebanese-Ties-Strengthen-Ahead-ofDisputed-Gas-Fields/ (accessed 16 August 2017).

Stergiou, A. (2017), "Energy and defense strategy in the Eastern mediterranean", Economics World, Vol. 5 No. 1, p. 107.

The Economist (2017), "Israel has a gas conundrum", available at: www.economist.com/news/middleeast-and-africa/21726744-egypt-could-help-israel-get-rid-its-excess-gas-israel-has-gas-conundrum (accessed 7 August 2017).

The Guardian (2015), "Eni discovers largest known gas field in mediterranean", available at: www. theguardian.com/business/2015/aug/30/eni-discovers-largest-known-mediterranean-gas-field (accessed 18July 2017).

Thompson, E. and Sarah, V. (2015), "Gas Discoveries in the Eastern Mediterranean: Implications for Regional Maritime Security, The German Marshall fund of the United States, Washington, DC, available at: www.gmfus.org/publications/gas-discoveries-eastern-mediterranean-implicationsregional-maritime-security (accessed 19 June 2017).

United States Institute of peace (2007), "Natural resources, conflict, and conflict resolution", Washington, DC.

US Energy information Administration (2013), "Overview of oil and natural gas in East Mediterranean region", available at: www.eia.gov/beta/international/analysis_includes/ regions_of_interest/Eastern_Mediterranean/eastern-mediterranean.pdf (accessed 6 March 2017).

US Geological survey (2010), "Assessment of undiscovered oil and gas resources of the levant basin province, Eastern Mediterranean”, World Petroleum Resources Project, Washington, DC, p. 1, available at: https://pubs.usgs.gov/fs/2010/3014/pdf/FS10-3014.pdf (accessed 10 July 2017).

Wainer, D. (2016), "US vision for mideast stability runs through gas pipelines", Bloomberg.com, available at: www.bloomberg.com/news/articles/2016-08-21/u-s-vision-for-mideast-stability-runsthrough-gas-pipelines (accessed 14 January 2017).

Wurmser, D. (2013), "The geopolitics of Israel's offshore gas reserves", Jerusalem center for public affairs, available at: http:/jicpa.org/article/the-geopolitics-of-israels-offshore-gas-reserves/ (accessed 6 October 2017).

Yeshayahou, K. (2012), "Delek, noble energy discover gas at Tanin well”, Globes, available at: www. globes.co.il/en/article-1000721723 (accessed 16 April 2017).

Yorgancioglu, C. (2015), "Solidarity with Palestine via energy projects and deals (Palestine-Russia)", Academia, available at: www.academia.edu/10331992/Solidarity_with_Energy_Projects_and_Deals_Palestine_Russia?auto=download (accessed 26 December 2017).

Zemach, S. (2016), Toward an Eastern Mediterranean Integrated Gas Infrastructure?, The German Marshall Fund of the United States, available at: www.gmfus.org/publications/toward-easternmediterranean-integrated-gas-infrastructure (accessed 23 October 2017). 
Cohen, H. (2015), "Russian gas COS mull Israel cooperation - Globes English", Globes, available at: www.globes.co.il/en/article-russian-gas-cos-mull-israel-cooperation-1001053121 (accessed 15 November 2017).

Ellinas, C., Robert, J., Tzimitras, H. and Koranyi, D. (2016), Hydrocarbon Developments in the Eastern Mediterranean: The Case for Pragmatism, Atlantic Council, Washington, DC, p. 17.

ELwerdany, S. (2017), "Egypt's giant Zohr gas field starts production”, Bloomberg, available at: www. bloomberg.com/news/articles/2017-12-16/egypt-says-eni-s-giant-zohr-gas-field-starts-firstproduction (accessed 2 January 2018).

Hanna, S. (2015), "Israel and offshore gas", National Council for Researches and Opinion Polls, available at: http://ncro.sy/?p=1952 (accessed 30 June 2016).

Pasquale, D. (2014), "The prospect of Eastern Mediterranean gas production: an alternative energy supply for the EU. IN-DEPTH ANALYSIS", Policy Department, Directorate-General for External Policies, European Parliament, Brussels, p. 20, available at: www.europarl.europa.eu/ RegData/etudes/briefing_note/join/2014/522339/EXPO-AFET_SP\%282014\%29522339_EN.pdf (accessed 25 July 2017).

Sukkarieh, M. (2017), "Russian expansionism”, The Executive Magazine, available at: www.executivemagazine.com/opinion/comment/russian-expansionism (accessed 20 September 2017).

Suzan, N. (2015), "Discovery of the decade: Eni's new deepwater find biggest ever in Egypt”, Egypt oil and gas newspaper, available at: http://egyptoil-gas.com/features/discovery-of-the-decade-enisnew-deepwater-find-biggest-ever-in-egypt/ (accessed 13 August 2017).

Vadim, S. and Itai, T. (2012), "Estimates for gas reserves in Shimshon field are cut sharply", HAARTEZ, available at: www.haaretz.com/israel-news/business/estimates-for-shimshon-gasreserves-cut-1.5174636 (accessed 15 June 2017).

\section{Corresponding author}

Ahmed ElBassoussy can be contacted at: A.elbassoussy@gmail.com

For instructions on how to order reprints of this article, please visit our website: 